\title{
ROBOTOKKAL A TERMÉSZET NYOMÁBAN
}

\section{ROBOTS IN THE WAKE OF THE NATURE}

Forgó Zoltán

\author{
Sapientia-EMTE, Marosvásárhelyi Kar, Gépészmérnöki Tanszék \\ 547367 Románia, Koronka 1C; Telefon:+40-265-208172, fax: +40-265-206211, \\ zforgo@ms.sapientia.ro
}

\begin{abstract}
The development of the mankind has its roots in the observation of the nature; the best practices were replicated and used by the early mans to survive along thousands of years. Nowadays, we like to think that we can respond to the everyday challenges with appropriate answers. But, to have really good working, optimal solutions, it is necessary to have a look to the managing way of our nature master. The efficiency of the living beings is the pledge of surviving, and it is developed beyond all praise by the nature: the only pursuit of us is to acquire those solutions. If we can ...
\end{abstract}

Keywords: biomimetics, robot, nature

\section{Összefoglalás}

Az emberiség fejlődése a természet megfigyelésével kezdődött; az ember innen leste el azokat a praktikákat, melyek a túlélést biztosították évezredeken keresztül. Szeretjük azt hinni, hogy a mindennapok különböző kihívásaira az ember képes megfelelő megoldást kigondolni. Viszont azért, hogy igazán jól müködjön, úgynevezett optimális megoldás szülessen, elengedhetetlen még napjainkban is a természet munkájának a megfigyelése és elemzése. Az élőlények energiahatékonysága nem kevesebb és nem több, mint a fajfennmaradás szükségessége, és ezt a természet tökéletességre fejlesztette: nekünk nincs más dolgunk csak lemásolni... ha tudjuk.

Kulcsszavak: biomimetika, robot, természet

\section{Bevezető}

A kezdetektől fogva az élőlények arra törekedtek, hogy kiaknázzák a környezetük adta lehetőségeket. Ez hozzásegítette őket, nemcsak a túléléshez, hanem tulajdonképpen a fejlödés motorja is lett. Nem volt másképp az ember esetében sem: megismerve a természetet, felfedezte azokat a lehetőségeket, melyeken keresztül könynyebbé tette az életét, melyek segítették energiatakarékosan berendezni hétköznapjait. Ez a jelenség megfigyelhető már az ősember idejében is, amikor az ,kölcsön- vette” az állatok bundáját, de a folyamat napjainkban is tart, amikor az emberiség olyan részleteket keres a természetben, melyeket beépítve az általa megvalósított berendezésekbe, ezek jobban szolgálják az ő szükségleteit.

A természet megvalósításainak a másolása mára már tudományággá fejlődött: megjelent a biomimetika, mely a biológia és a mérnöki tudományok szinergetikus összefonódásából alakult ki.

Ez tulajdonképpen két irányt jelent a tudományágban: esetenként egy tulajdonságot dokumentál és alkalmaz azokban a müszaki 
megoldásokban, melyekben hasonló fizikai jelenségek játszódnak le - vagy kell lejátszódniuk -, mint a természetben. A másik lehetőség egy olyan élőlény bizonyos mértékü másolásában rejlik, mely hordozza azokat a részleges vagy teljes tulajdonságokat, amelyeket az ember ki szeretne domborítani, illetve meg tud valósítani. Ennek következtében egy élölény megjelenését vagy viselkedésmódját reprodukálhatjuk.

\section{Tulajdonságok és egyedi megol- dások alkalmazása}

Ha a természetről hallunk, akkor első gondolatra talán az izgő-mozgó élőlények jutnak eszünkbe, viszont az ezek által kialakított élöhelyek is tele vannak tanulságokkal. A legjobb példa erre a zimbabwei Hararében, a 1990-es években épített Eastgate Centre (1. ábra), mely csekély fütés- és hütéstechnikával rendelkezik: a zöld növényzet és a megfelelő szellöztetörendszer biztosítja az egész éven át változatlanul kellemes, lakható hőmérsékletet. Ezek mellett a légkondicionáló rendszer üzemköltségeit sikerült, a hasonló nagyságú épületekhez képest, 90\%-al csökkenteni [1].

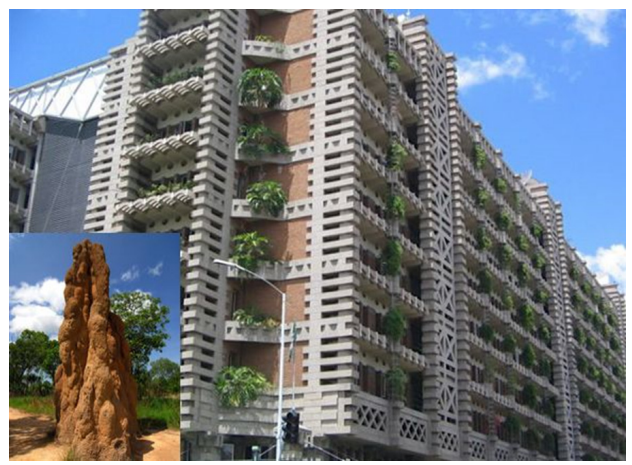

1. ábra. Az Eastgate Centre épület (Harare, Zimbabwe) tervezöi a termeszek épitkezéséböl ihletödtek a megfelelö szellöztetés érdekében.

Ezt a remek teljesítményt a termeszek építkezési stílusának alkalmazása tette lehetővé: míg a külső hőmérséklet 2 Celsius-fok (éjszaka) és 40 Celsius-fok (nappal) között ingadozik, a termeszeknek sikerül egy állandó 30 Celsius-fokos belső hőmérsékletet biztosítani, ami elengedhetetlen a táplálékukul szolgáló gombának az életben maradásához.

Egy másik ékes példa a japán vasúttársaság Sinkanszen (Bullet Train) vonatának az „orra” vagy találóbban fogalmazva a „csőre”. Mivel a vonat nagy sebességgel $(\approx 400 \mathrm{~km} / \mathrm{h})$ halad a pályán $[2]$, az alagutakból kijövet úgy viselkedik, mintha egészen más közegbe csapódna be, és ezt a jelenséget hangrobbanások jelzik. Egy mozdonyvezető tanácsára, aki lelkes madármegfigyelő volt, alakítottak a vonat mozdonyának elején úgy, (2. ábra), hogy ez hasonlítson a jégmadár csőrére, hiszen ez is nagy sebességgel csapódik a vízbe élelemszerzés során, viszont meglepően kis hullámokat kelt.
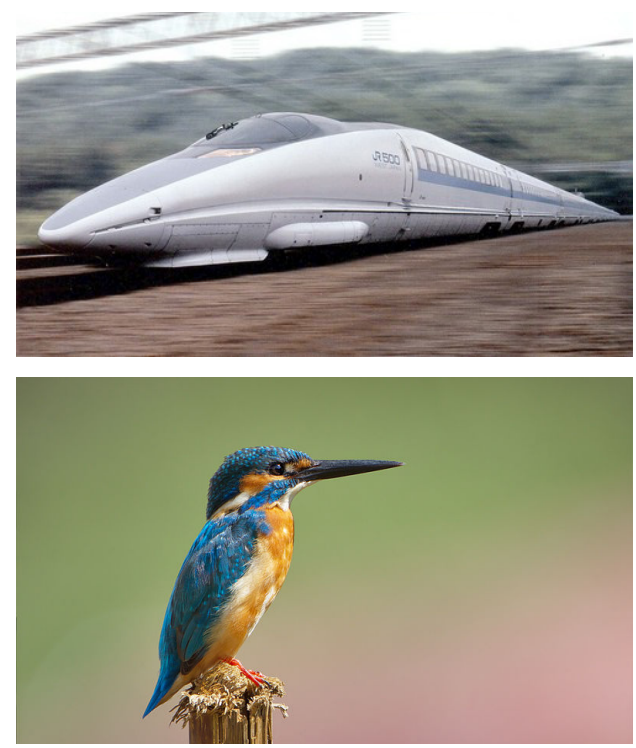

2. ábra. A japán vasúttársaság Sinkanszen (Bullet Train) vonata, melynek ,orr"kialakitása a jégmadár csörére hasonlit.

Az így átalakított vonat nemcsak halkabb lett, de 15 százalékkal kevesebb villamos energiát használ föl, és a sebessége is 
10 százalékkal növekedett. Mint sok más esetben is, a Mercedes-Benz gépkocsigyártó cég sem tudott eltekinteni a terméke eredeti alakjától, mivel ez az utastér jelentős csökkentését jelentette volna. 2005-ben megvalósítva viszont a Vörös-tenger lakójának, a sárga bőröndhalnak a formáját (3. ábra) egy $65 \%$-kal kisebb légellenállású jármüvet tudott elöállítani, mint bármely versenytársa.
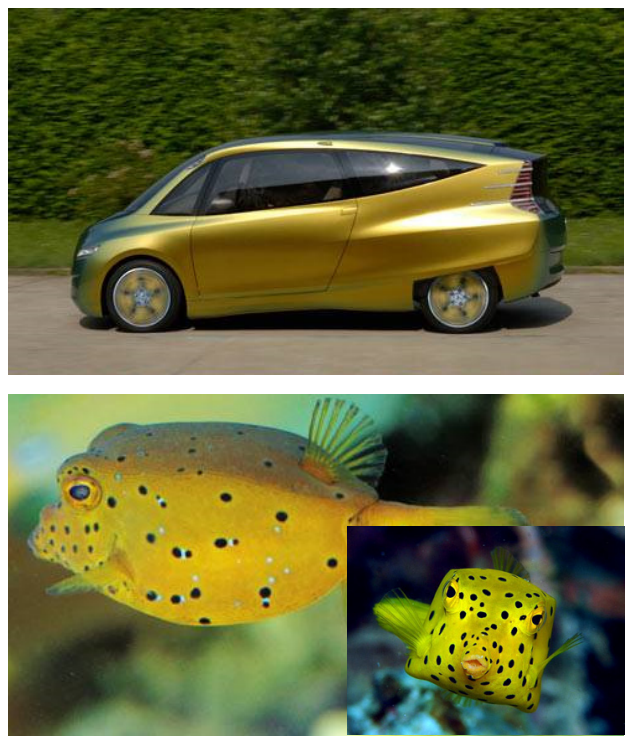

3. ábra. A Mercedes-Benz kompakt kategóriás tanulmányautója (2005), mely hozza a böröndhal alakját.

Újabb példa lehet a kála virág csavargörbéjének másolása (4. ábra). A kaliforniai székhelyü (Amerikai Egyesült Államok) PAX SCIENTIFIC cég egy olyan folyadékkeverő eszközt fejlesztett ki [3], amely az áramlástani megfontolások miatt, a szokásos keverőeszköz energiaszükségletének a töredékét használja, és így is gyorsabb keverődést biztosít.
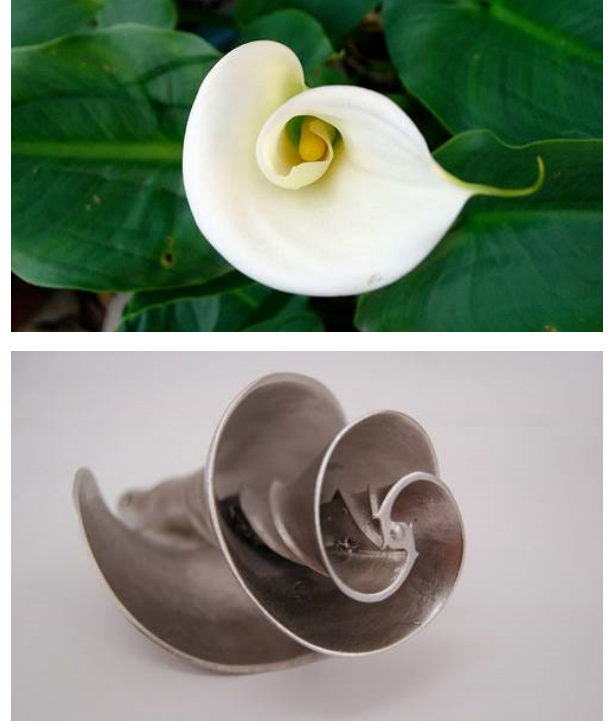

4. ábra. A kála virágjának alakját utánzó keverö szerszám energiaszükséglete töredéke a hagyományos szerszámhoz képest.
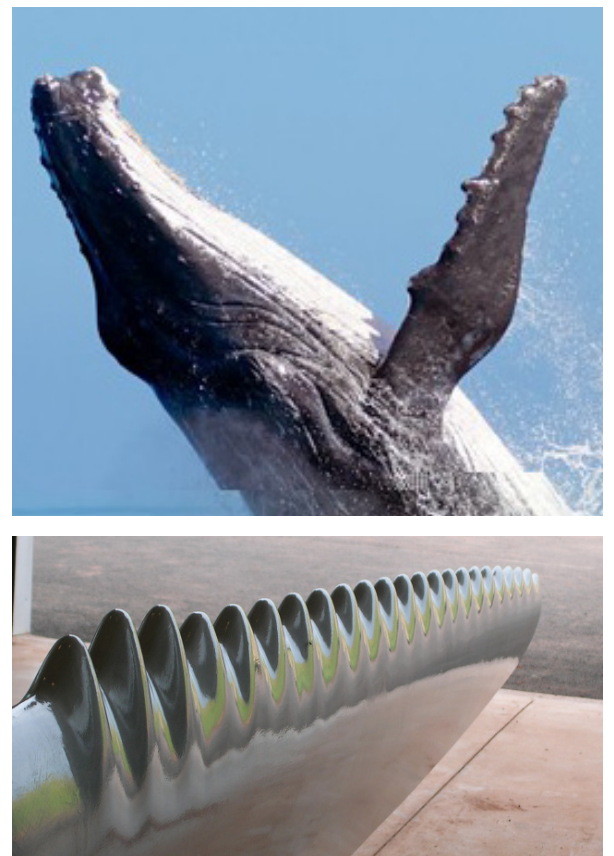

5. ábra. A szárnyas bálna uszonyformájának alkalmazása növelte a szélturbinák hatásfokát. 
Szintén a tengeren túl alapították a WhalePower Co. céget; ők a szárnyasbálna uszonyán levő kinövéseket vizsgálták és alkalmazták végül a szélturbina-lapátok felépítésében (5. ábra), és jobb eredményeket mértek a kísérletek alatt, mint várták volna: nőtt a generátor teljesítménye kis sebességü szél esetén, illetve csendesebb müködést tudtak biztosítani. Kapcsolódó esettanulmányokat a [4] tartalmaz.

Természetesen a sort lehetne folytatni, számos olyan megoldásnak az átültetése történt meg, mely hatékonyabbá teszi az ember által kitalált és megépített berendezéseket.

\section{3. Élőlény megjelenése és/vagy vi- selkedésmódjának alkalmazása}

Sok esetben a megfigyelésen alapuló müködő modellek tervezése és kivitelezése azt a kollektív tudásbázist gyarapítja, amelynek segítségével az ezután a látókörünkben felbukkanó kihívásokat sikerül megoldani. Így van ez azokkal a látványos robotokkal, melyek az állatvilágból merítenek ihletet, viszont nem egy tulajdonságot ültetnek át mesterséges környezetbe, hanem egy szervezetnek a müködését tárják fel.

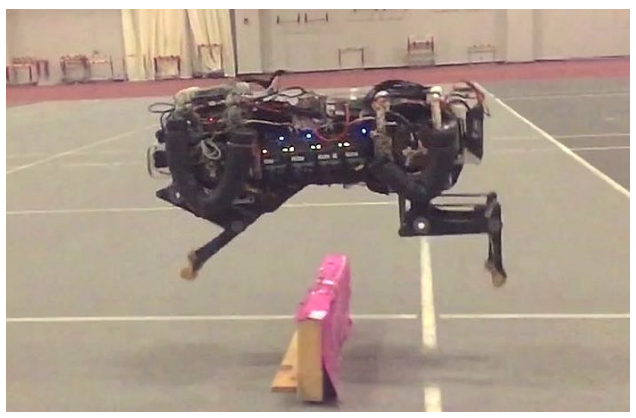

6. ábra. Az MIT Cheetah 2 robot, mely gátat tud ugrani $2,4 \mathrm{~m} / \mathrm{s}$ sebességnél.

A leglátványosabb megoldások, a helyváltoztatáshoz vagy a munkavégzéshez kapcsolódnak. Ennek nyomán jelentek meg az állatok és az ember mozgását utánzó berendezések, melyeknek a kutatása világ- méreteket öltött. Ennek az eredménye az MIT Cheetah (6. ábra) [5], mely önállóan galoppol, akadályt ugrik, és mindezt 2,4 m/s-os sebességgel.

Nem lehet befejezni anélkül, hogy ne említsük az emberszabású robotokat, amelyek az elmúlt években nagy fejlődést „szenvedtek” el. Világviszonylatban több neves kutatóközpont foglalkozik a kétlábú robot megvalósításával, de talán a Boston Dynamics cég (Amerikai Egyesült Államok) fejlesztett nagy lépésekkel [6].

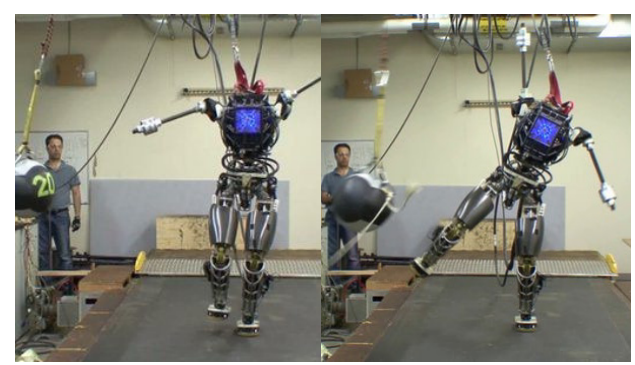

7. ábra. A Boston Dynamics cég Atlas robotja: egy lábon egyensúlyozva sikeresen kivédi a külsö mechanikai dinamikus terheléseket.

Csodálatos dolgokat tud az emberiség ellesni a természettől, hogy alkalmazva azokat könnyebbé, hatékonyabbá tegye az életét, viszont csakis hasonló dolgokat valósíthat meg, mivel teljesen reprodukálni ezeket mindmáig lehetetlen.

\section{Szakirodalmi hivatkozások}

[1] BIOMIMETIC ARCHITECTURE: Green Building in Zimbabwe Modeled After Termite Mounds. http://inhabitat.com/buildingmodelled-on-termites-eastgate-centre-inzimbabwe/ (2016.10.23.)

[2] High speed train silently slices through air. https://asknature.org/idea/shinkansentrain/\#.WRwZweuGPIU (2016.10.23.)

[3] http://paxscientific.com/ (2016.10.23.)

[4] https://whalepowercorp.wordpress.com/ (2016.10.23.)

[5] Dynamic Locomotion for the MIT Cheetah 2. https://biomimetics.mit.edu/research/dynamic -locomotion-mit-cheetah-2 (2016.10.23.)

[6] Atlas.www.bostondynamics.com/robot_Atlas .html (2016.10.23.) 